JMI Vol. 43 No. 2, Desember 2021

METAL INDONESIA

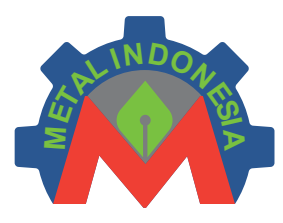

Journal Homepage:

http://www.jurnalmetal.or.id/index.php/jmi

p-issn: 0126-3463

e-issn: 2548-673X

\title{
PEMILIHAN MATERIAL RANGKA KENDARAAN PEMANEN JAGUNG KOMBINASI DENGAN METODE CRITIC, DIGITAL LOGIC DAN TOPSIS
}

\section{MATERIAL SELECTION FOR COMBINE CORN HARVESTER VEHICLES WITH CRITIC, DIGITAL LOGIC AND TOPSIS METHODS}

\author{
Martin Doloksaribu ${ }^{1,2, *}$, Agus Juniawan Khairi ${ }^{2}$, Muhammad Fathurrohman ${ }^{2}$, Sugeng Supriadi ${ }^{1}$ \\ ${ }^{1}$ Departemen Teknik Mesin, Fakultas Teknik, Universitas Indonesia, Kampus UI Depok, 16424 \\ ${ }^{2}$ Balai Besar Logam dan Mesin, Jalan Sangkuriang Nomor 12 Bandung 40135 \\ Jawa Barat, Indonesia \\ "mrtn.ds@gmail.com
}

\begin{abstract}
Abstrak
Desain rangka kendaraan pemanen jagung kombinasi menuntut rangka kendaraan yang memiliki berat dan kekuatan yang efisien selain kriteria sifat lain yang perlu dipertimbangkan. Pemilihan material dengan banyak kriteria merupakan hal rumit dan memerlukan metode yang tepat untuk meningkatkan probabilitas keberhasilan produk. Pemilihan material rangka kendaraan pemanen jagung kombinasi dilakukan dengan metode CRITIC, Digital Logic dan TOPSIS. Bobot kriteria dihitung dengan metode CRITIC dan Digital Logic. Kandidat material diurutkan dengan metode TOPSIS. Kandidat material terdiri dari dua golongan material yaitu aluminium dan baja struktur. Urutan pertama dengan bobot kriteria metode CRITIC dan metode DL adalah A7075-T6. Urutan kedua dengan metode CRITIC adalah A6061-T6 dan dengan metode DL adalah SSA710. Metode pemilihan material yang tepat dapat memberikan urutan material yang handal.
\end{abstract}

Kata kunci : CRITIC; Digital Logic; pemilihan material; rangka mesin pemanen jagung kombinasi; TOPSIS

\begin{abstract}
The frame of Corn Combine Harvester requires a combination of weight and strength besides other considered criteria. Material selection with many criteria is complex and requires appropriate methods to increase the probability of a successful product. material selection of a frame for corn combine harvester was carried out using the CRITIC, Digital Logic and TOPSIS methods. The criterion weights were calculated using the CRITIC and Digital Logic methods. Candidate materials were ranked by TOPSIS method. Material candidates were aluminum and structural steel. The first order material with criterion weights CRITIC method and DL method is A7075-T6. The second-order material with the CRITIC method is A6061-T6 and the DL method is SSA710. The appropriate material selection method can provide reliable material selection.
\end{abstract}

Keywords : CRITIC; Digital Logic; material selection; frame of combined corn harverster; TOPSIS

\section{PENDAHULUAN}

Rangka (sasis) kendaraan harus memiliki kriteria rasio berat (weight ratio) dan kekuatan (strength) yang tinggi (Nandhakumar et al., 2020;
Poulikidou et al., 2015; Rohith et al., 2018). Material rangka perlu memiliki konstruksi dan material dengan kekuatan tinggi karena rangka berperan menahan semua beban kendaraan 
(Kerebih Jembere et al., 2021; Wahyudi \& Fahrudi, 2017). Namun material rangka harus memiliki berat yang memadai agar berat keseluruhan kendaraan tetap efisien.

Kendaraan pemanen jagung kombinasi merupakan kendaraan yang memiliki modul memetik bonggol jagung, memisahkan kulit dari bonggol, memisahkan pipilan dari bonggol dan menampung pipilan jagung. Rangka sasis Mesin Pemanen Jagung Kombinasi telah didesain sesuai persyaratan. Total berat desain arsitektur kendaraan pemanen jagung (Gambar 1) sebesar $1300 \mathrm{~kg}$ (Doloksaribu et al., 2016). Simulasi pembebanan (force) menunjukkan beban maksimal yang diterima rangka sekitar $112 \mathrm{MPa}$ dengan profil rangka tubular (Gambar 2).

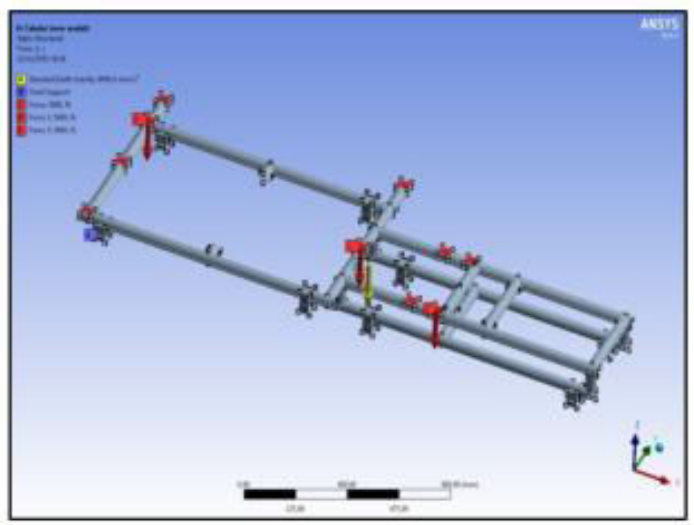

(a)

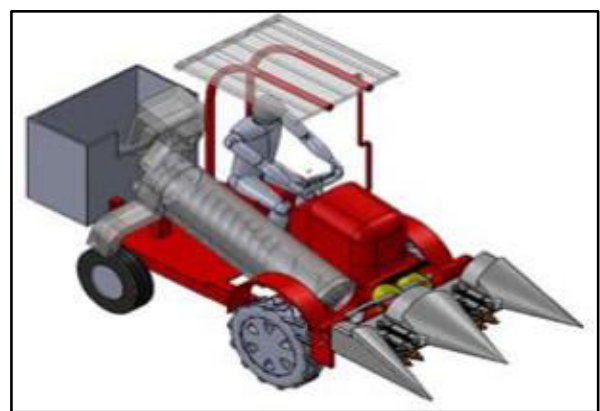

Gambar 1. Desain arsitektur (konsep desain) kendaraan pemanen jagung kombinasi

Sumber: dokumentasi penelitian

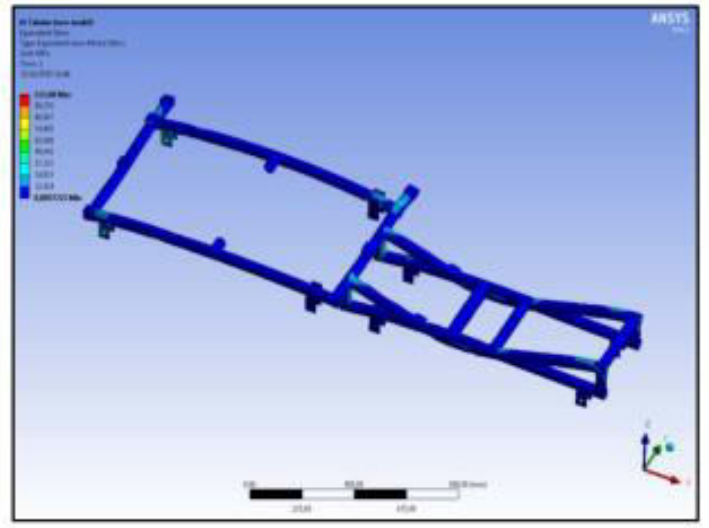

(b)

Gambar 2. (a) posisi beban, (b) simulasi pembebanan Sumber: (Doloksaribu et al., 2016)

Selain densitas dan kekuatan, Modulus Young menjadi pertimbangan dalam memilih material. Kendaraan digunakan pada lahan dengan kemiringan dan jalan bergelombang. Perubahan arah beban yang terjadi harus mampu diserap oleh rangka.

Memilih material dengan banyak kriteria menjadi proses yang rumit sehingga memerlukan strategi yang tepat (Antunes \& de Oliveira, 2014). Aluminium memiliki densitas yang lebih kecil daripada baja, namun pada umumnya baja memiliki kekuatan yang lebih baik. Baja memiliki Modulus Young sekitar 3 kali lebih besar dibandingkan aluminium.

Metode pemilihan material yang tepat dapat meningkatkan probabilitas memilih material yang tepat (Jahan \& Edwards, 2013). Pemilihan material perlu diseimbangkan dengan perspektif objektif dan subjektif. Material yang tepat dapat meningkatkan propabilitas keberhasilan produk.

Metode pemilihan material dengan banyak kriteria menggunakan Multi-Criteria Decision Method (MCDM) (Emovon \& Oghenenyerovwho, 2020). MCDM menggunakan pendekatan simultan terhadap benefit criteria dan cost criteria untuk mengambil keputusan. Beberapa cara (tools) MCDM yang banyak digunakan adalah AHP, VIKOR, MAUT, ELECTRE, Digital Logic dan TOPSIS.

Pekerjaan ini memilih material menggunakan beberapa metode yang tepat untuk 
kasus rangka kendaraan pemanen jagung kombinasi. Metode yang digunakan adalah criteria importance through inter-criteria correlation (CRITIC), digital logic (DL) dan technique for order preference by similarity to ideal solution (TOPSIS).

Metode tersebut memiliki beberapa pertimbangan untuk kasus rangka pemanen jagung kombinasi. Metode CRITIC menggunakan koefisien korelasi inter-kriteria untuk menghitung bobot kriteria. Koefisien tersebut menggambarkan secara statistik korelasi (saling mempengaruhi) antar kriteria (Jahan et al., 2012). Metode DL menggunakan perhitungan tingkat kepentingan antar kriteria untuk menghitung bobot kriteria. Kriteria yang paling penting akan memiliki nilai bobot kriteria yang besar. Metode TOPSIS digunakan untuk menunjukkan urutan kandidat material berdasarkan solusi ideal (Gheorghita \& Gheorghita, 2015; Singh et al., 2020).

\section{MATERIAL DAN METODOLOGI Material}

Kandidat material rangka kendaraan yang umum digunakan adalah aluminium dan baja struktur. Baja struktur memiliki yield strength tinggi dengan densitas tinggi. Sedangkan aluminium memiliki densitas di bawah baja struktur namun memiliki yield strength yang masih memadai.

Material aluminium dan baja struktur memiliki kisaran yield strength 200 550 MPa. Nilai Safety Factor rangka kendaraan direkomendasikan 1,5 2 (Patel et al., 2013). Pada beban maksimal sebesar $112 \mathrm{MPa}$ maka nilai beban desain sebesar $168 \mathrm{MPa}$. Kandidat material (Tabel 1) memiliki nilai yield strength lebih besar dari beban SF.

\section{Criteria importance through inter-criteria correlation (CRITIC)}

CRITIC merupakan metode perhitungan bobot secara objektif (Kumari \& Acherjee, 2021). Tahapan perhitungan sebagai berikut: (1) menormalkan nilai kriteria $\left(\bar{x}_{\mathrm{ij}}\right)$ (Persamaan 1); (2) menghitung standar deviasi $(\sigma)$ tiap kriteria
(Persamaan 2); (3) menghitung koefisien korelasi $\left(\mathrm{R}_{\mathrm{jk}}\right)$ (Persamaan 3); (4) menghitung bobot kriteria dengan Persamaan 4-5).

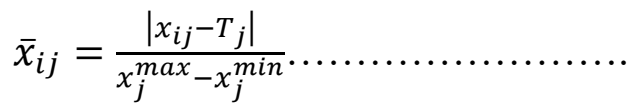

$$
\begin{aligned}
& \mathrm{i}=\text { material }=1, \ldots, \mathrm{m} \\
& \mathrm{j}=\text { kriteria }=1, \ldots ., \mathrm{n} \\
& \mathrm{T}_{\mathrm{j}}=\text { nilai target kriteria (min atau max) } \\
& \sigma_{j}=\sqrt{\frac{\sum_{i=1}^{m}\left(x_{i j}-\bar{x}_{j}\right)^{2}}{m}} \ldots \ldots \ldots \ldots \ldots \ldots \ldots \ldots \\
& \mathrm{j}=1, \ldots, \mathrm{n} \\
& R_{j, k}=\frac{\sum_{i=1}^{m}\left(x_{i, j}-\bar{x}_{j}\right)\left(x_{i, k}-\bar{x}_{k}\right)}{\sqrt{\sum_{i=1}^{m}\left(x_{i, j}-\bar{x}_{j}\right)^{2}-\sum_{i=1}^{m}\left(x_{i, k}-\bar{x}_{k}\right)^{2}}} . \\
& \mathrm{j}, \mathrm{k}=\text { pasangan kriteria } \\
& \mathrm{i}=\text { material }=1, \ldots, \mathrm{m} \\
& C_{j}=\sigma_{j} \times \sum_{k=1}^{m}\left(1-R_{j k}\right) \ldots \\
& W_{j}=\frac{C_{j}}{\sum_{k=1}^{m} C_{j}} \ldots
\end{aligned}
$$

\section{Digital Logic}

Metode DL membandingkan tingkat kepentingan antar kriteria (Dehghan-Manshadi et al., 2007). Tahapan perhitungan sebagai berikut: (1) membandingkan tingkat kepentingan antar kriteria; (2) menghitung jumlah positive decision tiap kriteria; (3) menghitung bobot kriteria (relative coefficient) dengan Persamaan 6.

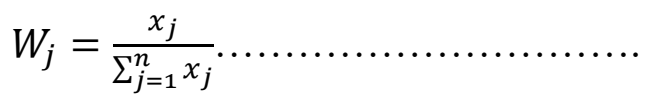

$\mathrm{j}=$ kriteria $=1, \ldots ., \mathrm{n}$

\section{TOPSIS}

Metode TOPSIS mengurutkan kandidat material berdasarkan kedekatan terhadap hipotesis solusi ideal positif dan hipotesis solusi ideal negatif. Solusi ideal positif adalah solusi yang memaksimalkan kriteria/atribut manfaat dan meminimalkan kriteria/atribut biaya. Solusi ideal negatif (solusi anti-ideal) merupakan solusi yang memaksimalkan kriteria biaya dan meminimalkan kriteria manfaat (Hutagalung et al., 2021). Bobot kriteria yang digunakan adalah bobot kriteria yang telah dihitung dengan CRITIC dan DL. Tahapan metode TOPSIS sebagai berikut: (1) menormalkan kriteria (Persamaan 7); (2) menghitung jarak ekludian dari ideal best $\left(\mathrm{S}_{\mathrm{i}}^{+}\right)$dan ideal worst $\left(\mathrm{S}_{\mathrm{i}}{ }^{-}\right)$ 
(Persamaan 8-9); (3) menghitung performance score (Pi) dengan Persamaan 10.

$$
\begin{aligned}
& \bar{X}_{i j}=\frac{X_{i j}}{\sqrt{\sum_{j=1}^{n} X_{i j}^{2}}} \ldots \ldots \ldots \ldots \ldots \ldots \ldots \ldots . . \\
& \mathrm{j}=\mathrm{kriteria}=1, \ldots, \mathrm{n} \\
& S_{i}^{+}=\sqrt{\sum_{j=1}^{n}\left(V_{i j}-V_{j}^{+}\right)^{2}} \ldots \ldots \ldots \ldots \ldots . \\
& S_{i}^{-}=\sqrt{\sum_{j=1}^{n}\left(V_{i j}-V_{j}^{-}\right)^{2}} \ldots \ldots \ldots \ldots \ldots . \\
& P_{i}=\frac{S_{i}^{-}}{S_{i}^{+}+S_{i}^{-}} \ldots \ldots \ldots \ldots \ldots \ldots \ldots \ldots \ldots \ldots \ldots
\end{aligned}
$$

\section{HASIL DAN PEMBAHASAN Bobot Kriteria dengan CRITIC}

Perhitungan bobot kriteria dengan metode CRITIC diawali dengan menormalkan nilai kriteria (Tabel 2). Pada kriteria D nilai target kriteria adalah nilai maksimal yaitu $7,85 \mathrm{~g} / \mathrm{cm}^{3}$. Sedangkan nilai target kriteria pada UTS, YS, MY dan E adalah nilai minimal yaitu adalah 270 $\mathrm{MPa}, 200 \mathrm{MPa}, 69 \mathrm{GPa}$, dan 5,20. Nilai kriteria yang telah dinormalkan dengan Persamaan 1 dan nilai standar deviasi $\left(\sigma_{\mathrm{j}}\right)$ ditunjukkan Tabel 2.

Tabel 3 menunjukkan nilai koefisien korelasi untuk pasangan kriteria. Nilai koefisien korelasi berkisar -1 sampai dengan 1. Koefisien ini menggambarkan hubungan linear antara dua kriteria. Nilai 1 menunjukkan kumpulan nilai dari dua kriteria berhubungan sempurna positif; jika kriteria pertama meningkat maka nilai kriteria kedua juga meningkat. Nilai -1 menunjukkan hubungan negatif; nilai kriteria pertama meningkat maka nilai kriteria kedua menurun. Nilai 0 menunjukkan tidak ada korelasi liner antara pasangan kriteria.

Kriteria D memiliki hubungan terbalik dengan semua kriteria lainnya. Kriteria tersebut memiliki korelasi yang erat dengan MY $(-0,999)$ dan E (-0,973). Nilai D yang semakin kecil (ringan) maka nilai MY dan E semakin besar. Korelasi ini sangat menguntungkan karena nilai D semakin kecil (ringan) maka MY, E, TS, dan YS semakin besar.

YS memiliki korelasi positif dengan TS $(0,749)$, MY $(0,271)$ dan E $(0,198)$. Nilai YS memiliki korelasi liner mendekati sempurna dengan TS. Nilai korelasi YS dengan MY dan E tidak terlalu besar sehingga YS semakin besar maka nilai MY dan E tidak terlalu meningkat.

Nilai bobot kriteria metode CRITIC ditunjukkan Tabel 4. Bobot terbesar dimiliki oleh D $(0,4099)$ diikuti oleh MY $(0,1813)$; E $(0,1556)$; YS $(0,1347)$ dan UTS $(0,1185)$.

Kandidat material diurut dengan metode TOPSIS. Pada metode TOPSIS diawali dengan menormalkan nilai kriteria dari tiap material dengan Persamaan 7. Hasil menormalkan nilai kriteria dengan Persamaan 7 dapat dilihat pada Tabel 5. Pada kriteria D, nilai ideal best adalah nilai minimal karena menginginkan material dengan D kecil. Pada TS, YS , MY dan E, nilai ideal best adalah nilai maksimal.

Urutan kandidat material dapat dilihat pada Tabel 6. AA7075-T6 berada pada urutan pertama diikuti oleh A6061-T6, AA356, SS710, SSA709 dan SSA36. Material AA7075-T6 memiliki perpaduan D (3,00 g/ $\left.\mathrm{cm}^{3}\right)$, TS (560 MPa) dan YS (480 MPa) yang baik. Material ini memiliki YS mirip dengan kelas baja struktural namun memiliki D lebih kecil.

\section{Bobot Kriteria dengan DL}

Perhitungan bobot kriteria dengan metode DL diawali dengan membuat perbandingan tingkat kepentingan antar kriteria. Tabel 7 menujukkan bobot kriteria metode DL. 
Tabel 1. Kandidat material dan nilai sifat (kriteria) material

\begin{tabular}{|c|c|c|c|c|c|c|c|}
\hline \multirow[t]{3}{*}{ No. } & Material & j & 1 & 2 & 3 & 4 & 5 \\
\hline & & & Max & Min & Min & Min & Min \\
\hline & & & $\begin{array}{l}\text { Density } \\
\text { (D) }\end{array}$ & $\begin{array}{l}\text { Tensile } \\
\text { Strength } \\
\text { (TS) }\end{array}$ & $\begin{array}{l}\text { Yield } \\
\text { Strength } \\
\text { (YS) }\end{array}$ & $\begin{array}{l}\text { Modulus Young } \\
\text { (MY) }\end{array}$ & $\begin{array}{l}\text { Elongation at } \\
\text { Break } \\
(\mathrm{E})\end{array}$ \\
\hline $\mathrm{i}$ & & & $\mathrm{g} / \mathrm{cm}^{3}$ & $\mathrm{MPa}$ & $\mathrm{MPa}$ & $\mathrm{GPa}$ & $\%$ \\
\hline 1 & Aluminium A356-T6 (AA356) & & 2,60 & 270 & 200 & 70,00 & 5,20 \\
\hline 2 & Aluminium 6061-T6 (A6061-T6) & & 2,70 & 320 & 270 & 69,00 & 10,00 \\
\hline 3 & Aluminium 7075-T6 (A7075-T6) & & 3,00 & 560 & 480 & 70,00 & 7,90 \\
\hline 4 & Structural Steel A709 (SSA709) & & 7,80 & 550 & 345 & 205,00 & 23,00 \\
\hline 5 & Structural Steel A710 (SSA710) & & 7,85 & 620 & 550 & 205,00 & 20,00 \\
\hline 6 & Structural Steel A36 (SSA36) & & 7,80 & 550 & 250 & 200,00 & 23,00 \\
\hline
\end{tabular}

Keterangan: ${ }^{1}$ casting, ${ }^{2,3}$ wrought,${ }^{4-6}$ plate

Sumber: (Indeck et al., 2021; Kiran et al., 2018; Nandhakumar et al., 2020; Nor et al., 2012; Rohith et al., 2018)

Tabel 2. Nilai kriteria yang telah dinormalkan dan nilai standar deviasi dengan metode CRITIC

\begin{tabular}{|c|c|c|c|c|c|c|c|}
\hline \multirow[t]{2}{*}{ No. } & \multirow[t]{3}{*}{ Material } & \multirow[t]{3}{*}{ j } & \multirow{3}{*}{$\frac{1}{D}$} & \multirow{3}{*}{$\begin{array}{c}2 \\
T S\end{array}$} & \multirow{3}{*}{$\begin{array}{c}3 \\
\mathrm{YS}\end{array}$} & \multirow{3}{*}{$\begin{array}{c}4 \\
\mathrm{MY}\end{array}$} & \multirow{3}{*}{$\begin{array}{l}5 \\
E\end{array}$} \\
\hline & & & & & & & \\
\hline $\mathrm{i}$ & & & & & & & \\
\hline 1 & Aluminium A356 Alloy (AA356) & & 1,000 & 0,000 & 0,000 & 0,007 & 0,000 \\
\hline 2 & Aluminium 6061-T6 (A6061-T6) & & 0,981 & 0,143 & 0,200 & 0,000 & 0,270 \\
\hline 3 & Aluminium 7075-T6 (A7075-T6) & & 0,924 & 0,829 & 0,800 & 0,007 & 0,152 \\
\hline 4 & Structural Steel A709 (SSA709) & & 0,010 & 0,800 & 0,414 & 1,000 & 1,000 \\
\hline 5 & Structural Steel A710 (SSA710) & & 0,000 & 1,000 & 1,000 & 1,000 & 0,831 \\
\hline \multirow[t]{2}{*}{6} & Structural Steel A36 (SSA36) & & 0,010 & 0,800 & 0,143 & 0,963 & 1,000 \\
\hline & standar deviasi $\left(\sigma_{j}\right)$ & & 0,482 & 0,379 & 0,361 & 0,492 & 0,413 \\
\hline
\end{tabular}

Tabel 3. Koefisien korelasi pasangan kriteria

\begin{tabular}{|c|ccccc|}
\hline $\begin{array}{c}\text { Koefisien } \\
\text { Korelasi } \\
\begin{array}{c}\text { Pasangan } \\
\text { Kriteria }\end{array}\end{array}$ & D & UTS & YS & MY & E \\
\hline D & 1,000 & $-0,749$ & $-0,293$ & $-0,999$ & $-0,973$ \\
TS & $-0,749$ & 1,000 & 0,749 & 0,720 & 0,702 \\
YS & $-0,293$ & 0,749 & 1,000 & 0,271 & 0,198 \\
MY & $-0,999$ & 0,720 & 0,271 & 1,000 & 0,970 \\
E & $-0,973$ & 0,702 & 0,198 & 0,970 & 1,000 \\
\hline
\end{tabular}

Tabel 4. Bobot kriteria metode CRITIC

\begin{tabular}{|c|c|c|c|c|c|c|c|c|c|}
\hline$\left(1-r_{j k}\right)$ & $\mathrm{D}$ & TS & YS & MY & $E$ & $\sum_{k=1}^{m}\left(1-r_{j k}\right)$ & $\sigma j$ & $C_{j}$ & $W_{j}$ \\
\hline$D$ & 0,000 & 1,749 & 1,293 & 1,999 & 1,973 & 7,014 & 0,482 & 3,3771 & 0,4099 \\
\hline UTS & 1,749 & 0,000 & 0,251 & 0,280 & 0,298 & 2,577 & 0,379 & 0,9764 & 0,1185 \\
\hline YS & 1,293 & 0,251 & 0,000 & 0,729 & 0,802 & 3,074 & 0,361 & 1,1099 & 0,1347 \\
\hline MY & 1,999 & 0,280 & 0,729 & 0,000 & 0,030 & 3,038 & 0,492 & 1,4936 & 0,1813 \\
\hline$E$ & 1,973 & 0,298 & 0,802 & 0,030 & 0,000 & 3,103 & 0,413 & 1,2815 & 0,1556 \\
\hline & & & & & & & $\sum_{k=1}$ & 8,2385 & \\
\hline
\end{tabular}


Tabel 5. Nilai normal bobot kriteria CRITIC

\begin{tabular}{clccccc}
\hline No. & Material & D & UTS & YS & MY \\
\hline 1 & Aluminium A356 Alloy (AA356) & 0,181 & 0,222 & 0,220 & 0,188 & 0,128 \\
2 & Aluminium 6061-T6 (A6061-T6) & 0,188 & 0,263 & 0,297 & 0,185 \\
3 & Aluminium 7075-T6 (A7075-T6) & 0,209 & 0,461 & 0,528 & 0,188 \\
4 & Structural Steel A709 (SSA709) & 0,543 & 0,452 & 0,379 & 0,551 \\
5 & Structural Steel A710 (SSA710) & 0,546 & 0,510 & 0,605 & 0,551 \\
6 & Structural Steel A36 (SSA36) & 0,543 & 0,452 & 0,275 & 0,565 \\
\hline
\end{tabular}

Tabel 6. Peringkat kandidat material dengan bobot CRITIC

\begin{tabular}{|c|c|c|c|c|c|c|c|c|c|c|}
\hline \multirow[t]{2}{*}{ No. } & Material & $\mathrm{D}$ & UTS & YS & MY & $E$ & $\mathrm{Si}^{+}$ & $\mathrm{Si}^{-}$ & $P_{i}$ & Ranking \\
\hline & Bobot CRITIC & 0,41 & 0,12 & 0,13 & 0,18 & 0,15 & & & & \\
\hline 1 & Aluminium A356 Alloy (AA356) & 0,0742 & 0,0262 & 0,0286 & 0,0338 & 0,0192 & 0,1107 & 0,1498 & 0,5752 & 3 \\
\hline 2 & Aluminium 6061-T6 (A6061-T6) & 0,0771 & 0,0311 & 0,0386 & 0,0334 & 0,0370 & 0,0953 & 0,1485 & 0,6090 & 2 \\
\hline 3 & Aluminium 7075-T6 (A7075-T6) & 0,0856 & 0,0543 & 0,0686 & 0,0338 & 0,0292 & 0,0874 & 0,1472 & 0,6274 & 1 \\
\hline 4 & Structural Steel A709 (SSA709) & 0,2226 & 0,0534 & 0,0493 & 0,0991 & 0,0850 & 0,1514 & 0,0991 & 0,3956 & 5 \\
\hline 5 & Structural Steel A710 (SSA710) & 0,2241 & 0,0602 & 0,0786 & 0,0991 & 0,0739 & 0,1503 & 0,1047 & 0,4108 & 4 \\
\hline 6 & Structural Steel A36 (SSA36) & 0,2226 & 0,0534 & 0,0357 & 0,0967 & 0,0850 & 0,1547 & 0,0956 & 0,3819 & 6 \\
\hline & Ideal Best $(\mathrm{V}+)$ & 0,0742 & 0,0602 & 0,0786 & 0,0991 & 0,0850 & & & & \\
\hline & Ideal Worst $\left(\mathrm{V}^{-}\right)$ & 0,2241 & 0,0262 & 0,0286 & 0,0334 & 0,0192 & & & & \\
\hline
\end{tabular}

Tabel 7. Bobot kriteria metode DL

\begin{tabular}{|c|c|c|c|c|c|c|c|c|c|c|c|c|c|}
\hline \multirow[t]{2}{*}{ No. } & \multirow[t]{2}{*}{ Kriteria } & \multicolumn{10}{|c|}{$\begin{array}{c}\text { Number of Decision } \\
N=n^{*}(n-1) / 2\end{array}$} & \multirow[t]{2}{*}{$\begin{array}{l}\text { Positive } \\
\text { Decision }\end{array}$} & \multirow[t]{2}{*}{$\begin{array}{c}\text { Relative } \\
\text { Coefficient }\end{array}$} \\
\hline & & 1 & 2 & 3 & 4 & 5 & 6 & 7 & 8 & 9 & 10 & & \\
\hline 1. & Density & 1 & 0 & 1 & 1 & & & & & & & 3 & 0,30 \\
\hline 2. & Tensile Strength & 0 & & & & 1 & 0 & 1 & & & & 2 & 0,20 \\
\hline 3. & Yield Strength & & 1 & & & 0 & & & 1 & 1 & & 3 & 0,30 \\
\hline 4. & Modulus Young & & & 0 & & & 1 & & 0 & & 0 & 1 & 0,10 \\
\hline 5. & Elongation & & & & 0 & & & 0 & & 0 & 1 & 1 & 0,10 \\
\hline & & & & & & & & & & & & 10 & 1,00 \\
\hline
\end{tabular}

Bobot terbesar dimiliki oleh D $(0,3)$ dan YS $(0,3)$ diikuti oleh TS $(0,2)$; MY $(0,1)$ dan E $(0,1)$. Penentuan tingkat kepentingan dipengaruhi oleh pertimbangan desain dan keahlian desainer. Dari bobot pada Tabel 7 terlihat bahwa D dan YS memberikan kontribusi yang besar dalam menentukan material yang terpilih.

Urutan material dengan bobot kriteria DL dapat dilihat pada Tabel 8. Urutan pertama adalah AA7075-T6 diikuti oleh SSA710, A6061T6, AA356, SSA709 dan SSA36. Aluminium AA7075-T6 pada urutan pertama karena memiliki perpaduan D dan YS yang baik.

\section{Perbedaan urutan CRITIC dan DL}

Perbedaan urutan material dengan bobot kriteria CTIRIC dan DL ditunjukkan Tabel 9. Beberapa material memiliki urutan yang sama pada bobot kriteria CRITIC maupun DL. Material A7075-T6 berada pada urutan pertama dan SSA709 berada pada urutan ke-5 baik pada bobot kriteria CRITIS dan DL. Material A7075T6 memiliki TS mirip beberapa material SS namun dengan D yang relatif kecil. Material ini baik untuk diguanakan pada rangka kendaraan pemanen jagung kombinasi.

Selain urutan pertama dan kelima, urutan material pada CRITIC dan DL terdapat perbedaan. Pada CRITIC dapat dilihat pada pengurutan terbagi menjadi kelompok material yaitu urutan 1-3 adalah kelompok material aluminium dan urutan 4-6 adalah structural steel. Urutan pada DL lebih acak di antara kelompok material.

Material urutan ke-2 pada CRITIC dan DL terdapat perbedaan. Pada CRITIC, urutan kedua adalah material A6061-T6. Material A6061-T6 memiliki D, TS, YS, MY lebih kecil dibandingkan AA7075-T6 (peringkat pertama) namun memiliki E lebih besar. Sedangan urutan ke-2 pada DL adalah SSA710. Material tersebut memiliki TS dan YS yang tidak berbeda jauh dengan AA7075-T6 namun dengan D yang lebih tinggi. Nilai TS dan YS SSA710 juga merupakan nilai terbesar dibandingkan dengan material lainnya. Subjektivitas desainer terlihat jelas pada pemilihan material metode DL karena YS 
merupakan kriteria yang diutamakan pada pemiliham

material.

Tabel 8. Urutan material dengan bobot kriteria DL

\begin{tabular}{|c|c|c|c|c|c|c|c|c|c|c|}
\hline \multirow[t]{2}{*}{ No. } & \multirow{2}{*}{$\begin{array}{l}\text { Material } \\
\text { Bobot DL }\end{array}$} & $\mathrm{D}$ & TS & YS & MY & $E$ & \multirow[t]{2}{*}{$\mathrm{Si}^{+}$} & \multirow[t]{2}{*}{$\mathrm{Si}^{-}$} & \multirow[t]{2}{*}{$\mathrm{P}_{\mathrm{i}}$} & \multirow[t]{2}{*}{ Ranking } \\
\hline & & 0,30 & 0,20 & 0,30 & 0,10 & 0,10 & & & & \\
\hline 1 & Aluminium A356 Alloy (AA356) & 0,0566 & 0,0468 & 0,0597 & 0,0195 & 0,0291 & 0,1324 & 0,1072 & 0,4475 & 4 \\
\hline 2 & Aluminium 6061-T6 (A6061-T6) & 0,0563 & 0,0547 & 0,0920 & 0,0186 & 0,0263 & 0,1031 & 0,1125 & 0,5218 & 3 \\
\hline 3 & Aluminium 7075-T6 (A7075-T6) & 0,0586 & 0,1010 & 0,1677 & 0,0194 & 0,0415 & 0,0370 & 0,1609 & 0,8132 & 1 \\
\hline 4 & Structural Steel A709 (SSA709) & 0,1638 & 0,0856 & 0,1150 & 0,0540 & 0,0470 & 0,1231 & 0,0791 & 0,3911 & 5 \\
\hline 5 & Structural Steel A710 (SSA710) & 0,1628 & 0,1034 & 0,1723 & 0,0554 & 0,0476 & 0,1064 & 0,1331 & 0,5556 & 2 \\
\hline \multirow[t]{3}{*}{6} & Structural Steel A36 (SSA36) & 0,1638 & 0,0812 & 0,0833 & 0,0540 & 0,0476 & 0,1413 & 0,0588 & 0,2937 & 6 \\
\hline & Ideal Best $(\mathrm{V}+)$ & 0,0563 & 0,1034 & 0,1723 & 0,0554 & 0,0476 & & & & \\
\hline & Ideal Worst $\left(\mathrm{V}^{-}\right)$ & 0,1638 & 0,0468 & 0,0597 & 0,0186 & 0,0263 & & & & \\
\hline
\end{tabular}

Tabel 9. Urutan dengan bobot kritera CRITIC dan DL

\begin{tabular}{clcc}
\hline No. & \multicolumn{1}{c}{ Material } & \multicolumn{2}{c}{ Ranking } \\
& & CRITIC & DL \\
\hline 1 & Aluminium A356 Alloy (AA356) & 3 & 4 \\
2 & Aluminium 6061-T6 (A6061-T6) & 2 & 3 \\
3 & Aluminium 7075-T6 (A7075-T6) & 1 & 1 \\
4 & Structural Steel A709 (SSA709) & 5 & 5 \\
5 & Structural Steel A710 (SSA710) & 4 & 2 \\
6 & Structural Steel A36 (SSA36) & 6 & 6 \\
\hline
\end{tabular}

Pengurutan dengan TOPSIS untuk bobot kriteria CRITIC dan DL menghasilkan urutan yang berbeda. Masing-masing pembobotan kriteria (CRITIC dan DL) memiliki kelebihan dan kekurangan. Pada CRITIC perhitungan bobot lebih objektif dibandingkan dengan DL. Pada DL, subjektivitas desainer menentukan kriteria utama mempengaruhi nilai bobot kriteria. Perpaduan penggunaan metode-metode dengan pendekatan yang berbeda dapat menghasilkan kandidat material yang sesuai.

\section{KESIMPULAN}

Pemilihan material dengan metode CRITIC, DL dan TOPSIS dapat memberikan solusi dalam pemilihan material rangka pemanen jagung kombinasi. Material urutan pertama dengan bobot kriteria metode CRITIC dan DL adalah AA7075-T6. Urutan kedua dengan bobot kriteria CRITIC adalah AA6061-T6 sedangan dengan bobot kriteria DL adalaah SSA710. Material AA7075-T6 cocok diguanakn pada rangka kendaraan pemanen jagung kombinasi karena memiliki perbaduan kekuatan dan berat yang baik. Validasi terhadap material yang terpilih perlu diteliti pada simulasi atau penerapan pada rangka kendaraan.

\section{UCAPAN TERIMA KASIH}

Penulis mengucapkan terima kasih kepada Peneliti di Balai Besar Logam dan Mesin yang telah mendukung kegiatan ini.

\section{DAFTAR PUSTAKA}

Antunes, R. A., \& de Oliveira, M. C. L. (2014). Materials selection for hot stamped automotive body parts: An application of the Ashby approach based on the strain hardening exponent and stacking fault energy of materials. Materials and Design, 63, 247-256.

https://doi.org/10.1016/j.matdes.2014.06.01 1

Dehghan-Manshadi, B., Mahmudi, H., Abedian, A., \& Mahmudi, R. (2007). A novel method for materials selection in mechanical design: Combination of non-linear normalization and a modified digital logic method. Materials \& Design, 28(1), 8-15. https://doi.org/10.1016/j.matdes.2005.06.02 3

Doloksaribu, M., Harbintoro, S., Khairi, A. J., \& Jamilah, S. (2016). Perancangan Rangka Kendaraan Mesin Pemanen Jagung Kombinasi terhadap Faktor Keamanan. $38(2)$.

Emovon, I., \& Oghenenyerovwho, O. S. (2020). Application of MCDM method in material selection for optimal design: A review. Results in Materials, 7(June), 100115. 
https://doi.org/10.1016/j.rinma.2020.10011 5

Gheorghita, C., \& Gheorghita, V. (2015). Materials Selection for an Engineering Application Using Multiple-Criteria Decision Analysis. Proceedings in Manufacturing Systems, 10(3), 141-146. http://www.icmas.eu/Journal_archive_files/ Vol_10-Issue3_2015_PDF/141146_Gheorghita_modified_02.pdf Hutagalung, C. Y., Latuconsina, R., \& Luhur, A. (2021). Sistem Pendukung Keputusan Pemilihan Tempat Makan di Bandung dengan Metode Technique for Order of Preference by Similiarity to Ideal Solution (TOPSIS). E-Proceeding of Engineering, 8(5), 6737-6745.

https://openlibrarypublications.telkomunive rsity.ac.id/index.php/engineering/article/vie w/16507/16216

Indeck, J., Demeneghi, G., Mayeur, J., Williams, C., \& Hazeli, K. (2021). Influence of reversible and non-reversible fatigue on the microstructure and mechanical property evolution of 7075-T6 aluminum alloy. International Journal of Fatigue, 145(October 2020), 106094. https://doi.org/10.1016/j.ijfatigue.2020.106 094

Jahan, A., \& Edwards, K. L. (2013). Weighting of dependent and target-based criteria for optimal decision-making in materials selection process: Biomedical applications. Materials and Design, 49, 1000-1008. https://doi.org/10.1016/j.matdes.2013.02.06 4

Jahan, A., Mustapha, F., Sapuan, S. M., Ismail, M. Y., \& Bahraminasab, M. (2012). A Framework for Weighting of Criteria in Ranking Stage of Material Selection Process. International Journal of Advanced Manufacturing Technology, 58(1-4), 411420. https://doi.org/10.1007/s00170-0113366-7

Kerebih Jembere, A., Paramasivam, V., Tilahun, S., \& Selvaraj, S. K. (2021). Stress analysis of different cross-section for passenger truck chassis with a material of ASTM A148 Gr 80-50. Materials Today:

Proceedings, $x x x x$. https://doi.org/10.1016/j.matpr.2020.12.985

Kiran, L., Kakkeri, S., \& Deshpande, S. (2018). Proposal of Hybrid Composite Material for Light Commercial Vehicle Chassis. Materials Today: Proceedings, 5(11),
24258-24267.

https://doi.org/10.1016/j.matpr.2018.10.221

Kumari, A., \& Acherjee, B. (2021). Selection of non-conventional machining process using CRITIC-CODAS method. Materials Today: Proceedings, $x x x x$.

https://doi.org/10.1016/j.matpr.2021.12.152

Nandhakumar, S., Seenivasan, S., Mohammed

Saalih, A., \& Saifudheen, M. (2020).

Weight optimization and structural analysis of an electric bus chassis frame. Materials

Today: Proceedings, $x$. https://doi.org/10.1016/j.matpr.2020.07.404

Nor, M. A. M., Rashid, H., Mahyuddin, W. M. F. W., Azlan, M. A. M., \& Mahmud, J. (2012). Stress Analysis of a Low Loader Chassis. Procedia Engineering, 41(Iris), 995-1001. https://doi.org/10.1016/j.proeng.2012.07.27 4

Patel, H., Panchal, K. C., \& Jadav, C. S. (2013). Structural Analysis of Truck Chassis Frame and Design Optimization for Weight Reduction. International Journal of Engineering and Advanced Technology (IJEAT), 2(4), 665-668.

Poulikidou, S., Schneider, C., Björklund, A., Kazemahvazi, S., Wennhage, P., \& Zenkert, D. (2015). A material selection approach to evaluate material substitution for minimizing the life cycle environmental impact of vehicles. Materials and Design, 83, 704-712. https://doi.org/10.1016/j.matdes.2015.06.07 9

Rohith, K. P., Sajay Rajan, E., Harilal, H., Jose, K., \& Shankar, K. V. (2018). Study and comparison of A356-WC composite and A356 alloy for an off-road vehicle chassis. Materials Today: Proceedings, 5(11), 25649-25656. https://doi.org/10.1016/j.matpr.2018.11.006

Singh, A. K., Avikal, S., Nithin Kumar, K. C., Kumar, M., \& Thakura, P. (2020). A fuzzyAHP and M - TOPSIS based approach for selection of composite materials used in structural applications. Materials Today: Proceedings, 26, 3119-3123. https://doi.org/10.1016/j.matpr.2020.02.644 Wahyudi, N., \& Fahrudi, Y. A. (2017). Studi Eksperimen Rancang Bangun Rangka Jenis Ladder Frame pada Kendaraan Sport. JEECAE (Journal of Electrical, Electronics, Control, and Automotive Engineering), 1(1), $71-75$. https://doi.org/10.32486/jeecae.v1i1.15 